\title{
EKSTREMIZAM NA INTERNETU IZAZOVI I PRILIKE NA ZAPADNOM BALKANU
}

\author{
MILO COMERFORD I SIMEON DUKIC
}

\section{SERIJA O ZAPADNOM BALKANU}

\section{${ }_{9}$ Ekstremistički ideolozi nisu ograničeni na širenje utjecaja u svojoj}

zemlji. Nego ekstremistička propaganda na internetu na zapadnom

Balkanu iskorištava i oslanja se na regionalne narative i demografiju.

\section{OSNOVNE ČINJENICE Kontekst}

$\rightarrow$ Jedinstvena demografija i povijest zapadnog Balkana znače da je ekstremizam na internetu regionalan problem koji nadilazi državne granice i doseg pojedinačnih vlada.

$\rightarrow$ Zemlje zapadnog Balkana moraju se paziti ekstremističkih skupina, polarizirajućih sila i neprijateljskih državnih dionika koji se služe digitalnim platformama kako bi iskoristili strahove i nezadovoljstva koja se pojavljuju u društvima predlaganjem supremacističkih i nasilnih rješenja.

$\rightarrow$ Prijetnja ekstremizma na internetu na zapadnom Balkanu prelazi granične nadležnosti zbog čega su međunacionalna surad-

nja i podrška susjednih zemalja ključne.
Zapadni Balkan suočava se s dvostrukim izazovom ekstremizma na internetu. Internetske platforme olakšavaju posebno izlaganje regije raznolikim međunarodnim ekstremističkim narativima. Istodobno se ekstremističke akcije i narativi iz cijelog svijeta opravdavaju regionalnim povijestima i geopolitikom. Navedena je dinamika bila posebno očita u ožujku 2019. kada je Brenton Tarrant izvršio razoran teroristički napad na muslimanska vjerska zdanja u Christchurchu u Novom Zelandu. Dok je Tarrant uživo prenosio trenutke do napada na društvenoj mreži Facebook, u pozadini se mogla čuti srpska nacionalistička pjesma povezana s jugoslavenskim ratovima koja je nedavno postala himna međunarodnoj alternativnoj desnici. ${ }^{1}$ I njegovo je oružjem, prekriveno imenima povijesnih

1 Murtaza Hussain, „From El Paso to Sarajevo: How White Nationalists have been Inspired by the Genocide of Muslims in Bosnia," The Intercept, 1. rujna 2019., https://theintercept.com/2019/09/01/ bosnian-genocide-mass-shootings/. 
ličnosti s Balkana koje su se opirale osmanlijskoj invaziji, upućivalo na povezanost s regijom čime je svoja djela povezao s usporednim otporom protiv „islamizacije”.

Prisutnost zapadnog Balkana u globalnoj internetskoj supkulturi ekstremne desnice povezana s radikalizacijom Australca Tarranta može se činiti nejasnom. Međutim, navedeni je fenomen dio većeg trenda koji naglašava sve veći izazov koji stvara širenje transnacionalnih ekstremističkih ideologija na internetskim platformama: od nasilnih džihadista do ekstremne desnice. $\mathrm{Na}$ zapadnom Balkanu to podrazumijeva niz posebnih rizika.

\section{Ekstremizam na internetu i zapadni Balkan}

Jedinstvena demografija i povijest zapadnog Balkana znače da je ekstremizam na internetu u biti regionalan problem koji nadilazi državne granice i doseg pojedinačnih vlada. Ekstremistički ideolozi nisu ograničeni na širenje utjecaja u svojoj zemlji. Nego ekstremistička propaganda na internetu na zapadnom Balkanu iskorištava i oslanja se na regionalne narative i demografiju. Mnogi ekstremistički ideolozi na zapadnom Balkanu, primjerice, imaju sljedbenike diljem regije čije se djelovanje u velikoj mjeri podudara s jezičnim granicama: etnički albanski salafi-džihadistički duhovni vođe $s$ Kosova imaju utjecaj u albanskim jezičnim zajednicama u Albaniji i Sjevernoj Makedoniji, ${ }^{2}$ dok su supremacistički srpski nacionalistički narativi namijenjeni srpskom stanovništvu diljem Srbije, Bosne i Hercegovine, Kosova i Crne Gore. Takvi regionalizirani ekstremistički narativi ne mogu se odvojiti od nasljeđā sukoba i dugotrajnih međuetničkih napetosti unutar regije.

Međunarodni ekstremistički utjecajnici izvan regije služe se internetom kako bi doprli do publike na zapadnom Balkanu s pomoću mnoštva međunarodnih internetskih stranica koje promoviraju sadržaj na lokalnim jezicima čime znatno prodiru u internetski prostor regije. Na primjer, neofašističke hrvatske skupine šire ekstremističke narative namijenjene zajednicama iseljenika na zapadnom Balkanu nastojeći revidirati hrvatsko ustaško nasljeđe iz Drugog svjetskog rata. ${ }^{3}$

Istodobno manji dijelovi zajednica iseljenika u zapadnoj Europi, Sjevernoj Americi i Australiji imaju glavnu ulogu kad je riječ o praćenju i širenju ekstremizma koji vuče korijene sa zapadnog Balkana na internetu. ${ }^{4}$ Nadalje, islamistički ekstremistički narativi također se usmjeravaju na stanovništvo zapadnog Balkana. IslamHouse, ugledna internetska stranica iz područja Zaljeva koja prenosi sadržaj brojnih islamističkih ekstremističkih duhovnih vođa, sadržava više od 9000 stavki sadržaja na jezicima zapadnog Balkana (u usporedbi sa 7000 dokumenata na engleskom jeziku). Stormfront, bjelački supremacistički portal iz Sjedinjenih Država, hvalio se 2015. sa 180000 objava na svom forumu usmjerenom na jugoistok Europe, uglavnom na zapadnom Balkanu. Srbija i Hrvatska tada su pokazale jedan od najvećih interesa za pretraživanje portala Stormfront na svijetu prema podacima usluge Google Trends. ${ }^{5}$

2 Vesë Kelmendi i Rudinë Jakupi, Countering the Myths of IS: How to Counter the IS Narrative Online? The Case of Albanian-Speaking Countries, Kosovski centar za sigurnosne studije, 2019., http://www.qkss.org/repository/docs/Countering-ISIS-myths-eng 724280.pdf.

3 Tijekom Drugog svjetskog rata dio Kraljevine Jugoslavije bio je pod nacističkom marionetskom državom koju je vodio hrvatski ustaški režim, koji je bio odgovoran za masovne zločine nad Židovima, Srbima i Romima. Više o skupinama dijaspore: Sven Milekic, „Croatia's Far Right Draws Strength from Diaspora," Balkan Insight, 5. siječnja 2018., https://balkaninsight. com/2018/01/05/croatian-far-right-draws-strength-from-diaspora-01-04-2018/.

4 „Balkan Terror Trials Reveal Links to Western Europe”, Balkanska istraživačka mreža, 9. siječnja 2018., https://balkaninsight. com/2018/01/09/balkan-terror-trials-reveal-links-to-western-europe-01-08-2018/.

5 Joseph Bernstein, „The Internet's United Nations of White Nationalists”, Buzzfeed News, 24. lipnja 2015., https://www. buzzfeednews.com/article/josephbernstein/the-internets-united-nations-of-white-nationalists. 
Internetski prostor donosi ekstremističke narative regija i na svjetsku pozornicu. Ti narativi uokviruju zapadni Balkan, s jedinstvenom vjerskom i kulturnom raznolikošću, kao prvu crtu bojišnice u civilizacijskom sukobu između kršćanskog i islamskog svijeta. U dorađenom propagandnom filmu iz 2015. ISIS je proglasio zapadni Balkan sljedećom „granicom” svjetskog džihada pred regijom i globalnom publikom. Narativ koji se ističe u videozapisu jest da su muslimani odavno podčinjeni u „ateističkim” i komunističkim albanskim i jugoslavenskim državama i da su pretrpjeli zločine protiv čovječanstva koje su počinili kršćani tijekom jugoslavenskih ratova. Na drugom kraju ekstremističkog spektra jedan je samoprozvani „kršćanski militantni red” iz Ujedinjene Kraljevine tvrdio da „ratuje preko interneta" u regiji kako bi privukao internetsku publiku od nekoliko desetaka milijuna ljudi svojim videozapisima na srpskom i hrvatskom. ${ }^{6}$ Skupina je također izvan granica interneta podržala skupine iz Kosova izdavanjem vojne opreme i odjeće radi pružanja podrške „prvoj crti bojišnice za zaštitu kršćanskog svijeta od islamske invazije". ${ }^{7}$

\section{Važnost za politiku i praksu}

Pokušaji stranih i domaćih državnih i ned ržavnih dionika da promoviraju destabilizaciju i manipuliraju regionalnim problemima koji dijele ljude mogu dovesti do većeg etničkog neslaganja, kao i moguće izloženosti radikalizaciji na zapadnom Balkanu. ${ }^{8}$ To je posebno istinito u kriznim situacijama, kao što je globalna pandemija bolesti COVID-19 koju različite skupine iskorištavaju kako bi izazvale paniku i antagonizam među različitim lokalnim zajednicama. ${ }^{9}$ Zemlje zapadnog Balkana moraju se paziti ekstremističkih skupina, polarizirajućih sila i neprijateljskih državnih dionika koji se služe digitalnim platformama kako bi iskoristili strahove i nezadovoljstva koja se pojavljuju u društvima predlaganjem supremacističkih i nasilnih rješenja. Međutim, također moraju razumjeti i usporedni izazov izvoza i instrumentalizacije narativa zapadnog Balkana ekstremističkih skupina izvan regije.

Trenutačno, prema našoj tekućoj analizi, rješenja koja se temelje na uklanjanju sadržaja ne djeluju, djelomično zbog neadekvatnog razumijevanja okružja prijetnji na internetu, nedostatka učinkovite suradnje između vlada, civilnih društava i tehnoloških društava te pokreta nezakonite aktivnosti na internetu za šifriranje platformi za razmjenjivanje poruka. Zabranjene skupine i pojedinci koje se kazneno progoni optužbama za terorizam zadržali su svoju prisutnost na internetu unatoč vladinim naporima da zauzda njihove aktivnosti. Na primjer, „džihadisti na društvenim mrežama” i dalje upotrebljavaju društvenu mrežu Facebook kako bi slobodno dijelili audiovizualni materijal i citate s propovijedi radikalnih imama koji trenutačno služe zatvorske kazne zbog novačenja pojedinaca u redove ISIS-a. ${ }^{10}$ lako je problem sprečavanja, ublažavanja i reguliranja ekstremizma na internetu svjetski problem, postoje brojne okolnosti specifične za regiju koje treba uzeti u obzir pri stvaranju učinkovite politike i stručnih odgovora.

6 JelenaCosic, Lawrence MarzoukilvanAngelovski, „British NationalistTrainsSerb Far-Rightfor 'OnlineWar'”,Balkan Insight, 1. svibnja 2018., http://www.balkaninsight.com/en/article/british-nationalist-trains-serb-far-right-for-online-war--04-30-2018.

7 Cosic, Marzouk, Angelovski, „British Nationalist.”

8 Sophie Eisentraut i Stephanie de Leon, Propaganda and Disinformation in the Western Balkans: How the EU Can Counter Russia's Information War (Berlin: Konrad Adenauer Stiftung, 2018.) 3-4, http://www.kas.de/wf/doc/kas 51729-544-2-30. pdf?180306092933.

9 Albana Shehaj, „After the Pandemic: Perils and Promise for Western Balkans,” Balkan Insight, 20. travnja 2020., https://balkaninsight.com/2020/04/20/after-the-pandemic-perils-and-promise-for-western-balkans/.

10 Vijeće za regionalnu suradnju, „Balkan 'Social Media Jihadis' More Dangerous than Ex-Fighters,” 20. prosinca 2019., https:// www.rcc.int/p-cve/news/259/balkan-social-media-jihadis-more-dangerous-than-ex-fighters. 


\section{Borba protiv radikalizacije na internetu smatra se prioritetom vlada zapadnog Balkana: ${ }^{11}$}

» Srpska strategija za suzbijanje nasilnog ekstremizma potvrđuje važnost objavljivanja protuporuka za suzbijanje radikalizacije na internetu.

» U makedonskoj strategiji raspravlja se o izgradnji kapaciteta za lokalne i vjerske zajednice u borbi protiv ekstremizma na internetu.

» U bosanskoj strategiji naglašava se važnost praćenja internetskog prostora, suprotnih narativa i ograničavanja internetske propagande.

» $U$ albanskoj nacionalnoj strategiji predstavljen je dvosmjeran pristup diskreditiranju i ublažavanju utjecaja ekstremističke propagande.

» U odjeljku kosovske strategije o radikalizaciji na internetu navodi se da je ISIS učinkovito pružao internetski prostor za raspravu i izradu poruka za učinkovitu potragu za novacima.

» U crnogorskoj strategiji predlaže se uspostava jedinice za rad u vezi s prijavljenim internetskim sadržajima za koordiniranje prepoznavanja terorističkih i nasilnih ekstremističkih sadržaja s partnerima.

Međutim, unatoč prioritizaciji nema dovoljno dokaza o konkretnim inicijativama i vladinim aktivnostima u borbi protiv ekstremističkih narativa na internetu ni na regionalnoj ni na nacionalnoj razini.

Premda postoje brojni pokušaji građanske protupropagande, uglavnom od islamskih skupina koje pokušavaju opovrgnuti ekstremistička vjerska tumačenja, navedeni napori nisu uvijek imali koristi od nacionalnih ili međunarodnih stručnih savjeta o strateškim komunikacijama ili dovoljno resursa i podrške za učinkovito suočavanje s prijetnjom iz poruka koje šalju ekstremističke skupine. Primjerice, jedan portal za protupropagandu, Fol Tash (Speak Now), koji vode islamski teolozi, pokušava se suprotstaviti islamističkim ekstremističkim narativima, ali ne može doprijeti do ranjive publike koja bi mogla biti u najvećoj opasnosti od nasilne islamističke propagande. ${ }^{12}$ Razmatrajući širi globalni deficit, napori za borbu protiv ekstremizma krajnje desnice usmjerenog na zapadni Balkan na internetu bili su još manje rašireni. ${ }^{13}$ Općenito, preko društvenih mreža i širih sfera

11 Vijeća ministara Republike Albanije (Odluka br. 930), Albanian National Strategy: Countering Violent Extremism, Narodne novine Republike Albanije (203/2015), 18. studenog 2015., neslužbeni prijevod, https://cve.gov.al/wp-content/uploads/2018/11/strategiia-2018-me-ndryshime.pdf; Republika Kosovo, Ured premijera, Strategy on Prevention of Violent Extremism And Radicalisation Leading to Terrorism 2015-2020, (Priština: rujan 2015.), https://wb-iisg.com/wp-content/uploads/ bp-attachments/6122/STRATEGY-on-PVERLT parandalim - ENG.pdf; Bosna i Hercegovina, Vijeće ministara, Strategy of Bosnia and Herzegovina for Preventing and Combating Terrorism 2015-2020, (Sarajevo: 2015.), https://wb-iisg.com/wp-content/uploads/bp-attachments/6102/STRATEGIJA ZA BORBU PROTIV TERORIZMA ENG.pdf; Vlada Crne Gore, Ministarstvo pravosuđa, Countering Violent Extremism Strategy 2016-2018, (Podgorica: prosinac 2015.), https://wb-iisg.com/wp-content/ uploads/bp-attachments/6160/Countering-violent-extremism-strategy-2016-2018.pdf; Vlada Republike Makedonije, Nacionalni odbor za suzbijanje nasilnog ekstremizma i suzbijanje terorizma, National Counterterrorism Strategy of the Republic of Macedonia (2018-2022), (Skopje: veljača 2018.), https://wb-iisg.com/wp-content/uploads/bp-attachments/6135/ct national strategy eng translation sbu.pdf; Vlada Republike Srbije, National Strategy for the Prevention and Countering of Terrorism for 2017-2021, https://wb-iisg.com/wp-content/uploads/bp-attachments/6200/Serbian-National-Strategy-for-the-prevention-and-countering-of-terrorism-for-2017-2021.docx.pdf.

12 Kelmendi and Jakupi, Countering the Myths of IS.

13 Jacob Davey, Henry Tuck i Amarnath Amarasingam, An Imprecise Science: Assessing Interventions for the Prevention, Disengagement and De-radicalisation of Left and Right-wing Extremists (London: ISD Global, studeni 2019.), https://www.isdglobal. org/wp-content/uploads/2019/11/An-imprecise-science.pdf. 
interneta napori u borbi protiv propagande na internetu većinom nisu uspjeli postati popularni i učinkovito konkurirati ekstremističkom sadržaju na internetskom prostoru.

Prepoznavanjem tih nedostataka i nedostataka u regionalnim i globalnim odgovorima ova studija o politici pruža preporuke političarima i stručnjacima koji se pokušavaju baviti i suprotstaviti ekstremističkim aktivnostima i narativima usmjerenima na zapadni Balkan na internetskom prostoru prije nego što nastane još više štete.

\section{Preporuke za politike}

\section{Izgradite naše razumijevanje dinamičnoga okružja prijetnje.}

Očajno nam treba trajni prikaz sve veće prijetnje radi omogućavanja strateških i učinkovitih odgovora vlada, stručnjaka, civilnog društva i privatnog sektora za učinkovitu borbu protiv ideologija nasilnog ekstremizma na internetu i izvan njega. Stoga je razvoj strukture pouzdanih podataka i odgovora ključan. Poboljšana slika podataka omogućit će vladama da bolje razumiju opasnosti na internetu povezane s ekstremističkim narativima, dezinformacijama i govorima mržnje te odrede mreže koje su ključne za njihovo širenje dok istodobno osiguravaju poštovanje ljudskih prava i privatnosti. Posebno je važno da su svi takvi napori društva namjerno transparentni radi zaštite od njihove moguće primjene u političke svrhe.

I tvorci politika trebaju prepoznati i reagirati na ovo promjenljivo okružje i razvijajuću organizacijsku dinamiku nasilnog ekstremizma. Naime, vlade moraju razviti političke i pravne okvire koji na odgovarajući način rješavaju sve decentraliziraniju, postorganizacijsku prirodu s masovnom potporom krajnje desnog terorizma i osigurati da se previše ne oslanjaju na zabranjene terorističke skupine koje ne uspijevaju uhvatiti raznolikost suvremene prijetnje nasilnog ekstremizma na internetu. Vlade bi istodobno trebale uložiti veće napore kako bi reagirale na zakonite, ali svejedno štetne sadržaje, poput govora mržnje na internetu, tako da razmotre koliko je primjenjiv pristup „dužnosti brižnog postupanja" na temelju rizika za poticanje regulacije platformi. Ovaj bi se pristup trebao usredotočiti na očuvanje sigurnosti korisnika te pomoći reakcijama civilnog društva većim resursima i jačanjem kapaciteta za osnaživanje vjerodostojnih glasova kako bi se ispunila ta ključna praznina. ${ }^{14}$

\section{Ulaganje u regionalnu stručnost radi rješavanja slabo vidljivih jezičnih pitanja.}

I džihadistički i krajnje desni ekstremistički sadržaji na jezicima zapadnog Balkana prevladavaju na internetskim prostorima u vidu sadržaja na albanskom, srpskom i bosanskom jeziku koji su lako dostupni na platformama društvenih mreža i putem tražilica. ${ }^{15}$ Dok globalna tehnološka poduzeća nastoje pružiti dosljedno i standardizirano iskustvo korisnicima diljem svijeta, učinkovito upravljanje platformama zahtijeva lokalizirano razumijevanje jezika i kulture. S tim na umu, pri provedbi slojevitog odgovora na ekstremizam na internetu globalna tehnološka poduzeća trebala bi ulagati u jačanje stručnosti za odgovarajuća humanistička područja kako bi se osiguralo precizno razumijevanje prijetnji i izazova na zapadnom Balkanu te jačanje provedbenih kapaciteta

14 Primjer te vrste programa je ISD-jeva inicijativa za građansku hrabrost na internetu, koja djeluje diljem Europe kako bi poboljšala vještine i unaprijedila građanske reakcije na mržnju i ekstremizam. Pogledajte: https://www.isdglobal.org/programmes/ communications-technology/online-civil-courage-initiative-2-2/.

15 Nedavna istraživanja o ekstremizmu na internetu u regiji zapadnog Balkana provodi niz stručnjaka među kojima su Adrian Shtuni, institut Tony Blair Institute for Global Change, poduzeće Moonshot CVE, Kosovski centar za sigurnosne studije i Balkanska istraživačka mreža. 
i mogućnosti za ispravljanje. Budući da većina poduzeća društvenih mreža nema predstavnike na zapadnom Balkanu, iznimno je važno istražiti metode jačanja suradnje s vladama kako bi zajednički osmislili strategije za suzbijanje ekstremističkih poruka. Transparentnim procesom između vlada i tehnoloških poduzeća, u dogovoru sa stručnjacima i civilnim društvom, trebalo bi se odrediti koji izazovi na internetu udovoljavaju potrebnim kriterijima za pravne i regulativne mjere uz potpuno poštovanje ljudskih prava.

\section{Napuštanje moderiranja sadržaja.}

Razmatranja koja se vrte oko reguliranja tehnoloških platformi moraju napustiti moderiranje sadržaja kako bi obuhvatili algoritamsko povećanje ekstremističkih poruka i šireg ekosustava ekstremizma na internetu, uključujući način na koji algoritmi za pretraživanje i davanje preporuka možda navode ljude prema ekstremističkom sadržaju na internetu. Iako su postignuti samo mali koraci prema širenju napora za suzbijanje odmicanjem od pukog uklanjanja sadržaja, sustavni napori još uvijek nisu započeli. Nedavne objave društvene mreže Facebook pokazale su ograničene odgovore poduzeća na dublje algoritamske probleme u pogledu ekstremizma na internetu unatoč internim istraživanjima iz 2016. prema kojima „64 \% svih ljudi koji se pridruže ekstremističkim skupinama to čine zbog alata za preporuku [platforme]."16

\section{Razvoj regionalnog odgovora na regionalni izazov.}

Prijetnja ekstremizma na internetu na zapadnom Balkanu prelazi granične nadležnosti zbog čega su međunacionalna suradnja i podrška susjednih zemalja ključne. To je posebno važno kod jezičnih zajednica koje se protežu preko granica. Ovaj je izazov prepoznat i u zajedničkom akcijskom planu borbe protiv terorizma na zapadnom Balkanu u kojem su se vlade u regiji obvezale na suzbijanje terorističkog sadržaja na internetu upućivanjem terorističkog sadržaja internetskim poduzećima i osnaživanjem partnera civilnog društva da razviju učinkovite alternativne narative. ${ }^{17}$

Međutim, malo je pojedinosti o konkretnim mehanizmima suradnje. Zemlje zapadnog Balkana imaju slobodu u pronalaženju zajedničkih rješenja za ovaj problem. Uspostava regionalne radne skupine koja bi okupila relevantne državne službe, uključujući agencije za provedbu zakona i elektroničke komunikacije, kako bi odredila regionalne prijetnje, razmjenjivala iskustva i razvijala koordinirane odgovore povećala bi napore u borbi protiv iskorištavanja interneta koje vrše ekstremistički i teroristički dionici. Mogla bi se izraditi na temelju dvogodišnjih sastanaka između nacionalnih koordinatora sprečavanja / borbe protiv nasilnog ekstremizma koji se organiziraju u okviru EU-a radi poticanja takve suradnje. Okupljanje tvoraca politika i stručnjaka iz različitih sektora radi dijeljenja znanja i boljeg shvaćanja potencijalnih učinaka odgovora na opasnosti na internetu-uključujući digitalnu regulaciju, obrazovanje o digitalnom državljanstvu i komunikacijske intervencije - pomaže potkopati i suzbiti štetne učinke dezinformacija na internetu, govora mržnje i ekstremizma. ${ }^{18}$

16 Jeff Horwitz iDeepa Seetharaman, „Facebook Executives Shut Down Efforts to Make the Site Less Divisive," Wall Street Journal, 26. svibnja 2020., https://www.wsj.com/articles/facebook-knows-it-encourages-division-top-executives-nixed-solutions-11590507499.

17 „Joint Action Plan on Counter-Terrorism for the Western Balkans,” Europska komisija, 5. listopada 2018., https://ec.europa. eu/home-affairs/sites/homeaffairs/files/news/docs/20181005 joint-action-plan-counter-terrorism-western-balkans.pdf.

18 ISD-jeva mreža digitalnog laboratorija politika i tvoraca politika nastoji izgraditi međunarodnu „zajednicu prakse” među tvorcima politika i tehnološkim stručnjacima u odnosu na pitanja digitalne politike. Pogledajte: https://www.isdglobal.org/ programmes/policy-government-advisory/policy-planners-network/. 


\section{Partner sa širim civilnim društvom i lokalnim zajednicama.}

Prema nedavnom izvješću British Councila o ekstremizmu na zapadnom Balkanu, ispitanici smatraju da suprotne narative treba uvrstiti u strateško preventivno stvaranje programa u regiji. ${ }^{19}$ Međutim, zemlje zapadnog Balkana pate od relativno niskih stopa javnog povjerenja u nacionalne vlade, pa bi učinkovitost bilo kojeg vladinog strateškog komunikacijskog plana prihvaćanja i podrške šireg civilnog društva bila ograničena. ${ }^{20}$ Napori za suzbijanje nasilnog ekstremizma trebaju primijeniti cjelokupni društveni pristup kako bi se osiguralo prihvaćanje zajednice i osnaživanje napora civilnog društva za suočavanje s nasilnim ekstremizmom, koji takvim inicijativama može pružiti jedinstven izvor, odjek i vjerodostojnost. Nadalje, u ovaj je napor potrebno uključiti i gradove i lokalne zajednice jer se ekstremizam manifestira drukčije na drukčijim mjestima, a lokalne vlasti i organizacije mogu ponuditi prilagođene odgovore na temelju jedinstvenog konteksta. ${ }^{21}$

Postoje određeni poučni lokalni primjeri o tome kako taj pristup cjelokupnom društvu može izgledati u praksi. Mreža Strong Cities Network (SCN) podupire uspostavu i operativnu provedbu modela „mreže lokalne prevencije” za pokretanje pristupā pod vodstvom općina i s podrškom civilnog društva u Kumanovu u Sjevernoj Makedoniji. U tom je kontekstu višedionički subjekt pod nazivom akcijski tim zajednice zadužen za razvoj, koordinaciju i provedbu lokalnih strategija u skladu s Nacionalnom strategijom borbe protiv nasilnog ekstremizma, kao i za zajedničko planiranje i provedbu aktivnosti s vladinim i nevladinim organizacijama prilagođenim ključnim lokalnim prioritetima. ${ }^{22}$ Centar Centre for Common Ground podržao je i razvoj akcijskih timova zajednice u općinama Čair (Skopje), Gostivar i Kičevo u Sjevernoj Makedoniji na temelju modela lokalne prevencije. ${ }^{23}$

\section{Promicanje vještina digitalnog državljanstva u okviru civilnog obrazovanja.}

Indeks medijske pismenosti, koji je sastavio Institut otvoreno društvo, pokazuje da je zapadni Balkan među najranjivijim regijama u Europi kad je riječ o mogućim internetskim opasnostima. ${ }^{24}$ Sve države zapadnog Balkana ${ }^{25}$ nalazile su se na posljednja dva kvintila za medijsku pismenost i otpornost na dezinformacije, a Sjeverna Makedonija ima najniži ukupni rezultat u Europi. ${ }^{26}$ Istraživanja pokazuju

19 Vlado Azinović, Regional Report: Understanding Violent Extremism in the Western Balkans (British Council: 2018.), https:// www.britishcouncil.me/sites/default/files/erf report western balkans 2018.pdf.

20 "Serbia the only WB country with more trust in the government than in the EU,” European Western Balkans, 6. kolovoza 2019., https://europeanwesternbalkans.com/2019/08/06/serbia-the-only-wb-country-with-more-trust-in-the-government-thanin-the-eu/.

21 Strong Cities Network, globalna mreža gradonačelnika, gradskih dužnosnika i stručnjaka koji su predani razmjeni najboljih praksi u suzbijanju nasilnog ekstremizma i polarizacije, ima članstvo od 44 općine iz cijele regije koje su posvećene stvaranju otpornih posebnih područja. Time se može pojednostavniti jačanje partnerstava i razvoj strateške komunikacije za gradove. Nadalje, mreža je svojim programom Young Cities podržala skupine mladih za razvoj inicijativa u zajednicama koje vode pod vodstvom mladih, neke u obliku kampanja sa suprotnim narativima.

22 Besim Dogani i Nayla Joy-Zein, "SCN's Local Prevention Network Model Expands to the Western Balkans," Strong Cities Network, 9. listopada 2019., https://strongcitiesnetwork.org/en/lpn-model-expands-to-the-western-balkans/.

23 Više o centru Centre for Common Ground potražite na njihovoj internetskoj stranici: https://ccg.org.mk/.

24 Marin Lessenski, „Just Think about It: Findings of the Media Literacy Index 2019,” Open Society Institute, Policy Brief 55, 2019. https://osis.bg/wp-content/uploads/2019/11/MediaLiteracylndex2019 -ENG.pdf.

25 Kosovo nije uključeno u studiju zbog nedovoljnih podataka.

26

Lessenski, „Just Think about It." 
da su vještine digitalne pismenosti ključne za izgradnju otpornosti na ekstremizam, polarizaciju i radikalizaciju. ${ }^{27}$ Obrazovanje učinkovitog digitalnog državljanstva bit će ključno kako bi mladi dobili potrebno znanje, alate i samopouzdanje za snalaženje u pogledu međupovezanih izazova na internetu i izvan njega - uključujući izazove u vidu lažnih vijesti, dezinformacija i teorija zavjere među mladima i starima. ${ }^{28}$

Aktivnim razvojem kurikula, programa osposobljavanja nastavnika i resursa za učenje koji pružaju znanje i vještine za razvoj kritičkog razmišljanja, promicanjem otvorenih stavova, civilnog angažmana i međukulturnog suživota, vlade mogu izgraditi veću otpornost na ekstremističke narative, kampanje zlonamjernog utjecaja i druge internetske opasnosti. lako je EU-ova Digitalna agenda za zapadni Balkan iz 2019. usredotočena na promoviranje digitalne pismenosti u regiji, važno je da inicijative sadržavaju ideje pozitivnog građanstva u digitalnoj sferi i podržavaju otpornost protiv niza internetskih opasnosti. ${ }^{29}$ Navedene aktivnosti ne bi trebalo ograničiti samo na formalno obrazovanje, već bi ih trebalo proširiti na neformalno obrazovanje i kampanje podizanja svijesti kako bi se osiguralo da i mlade i starije generacije, koje su jednako pogođene internetskim opasnostima, imaju koristi od veće osviještenosti i razumijevanja dezinformacija i ekstremističkih narativa na internetskom prostoru.

\section{Zaključak}

Zapadni Balkan suočen je s brojnim regionalnim izazovima i pitanjima oko internetskog ekstremizma koji proizlaze iz njegove jedinstvene povijesti, raznolike demografije i geopolitičkog položaja, što ima važne posljedice za donošenje koherentnih politika. Međutim, u tom širem regionalnom kontekstu znatno različite nacionalne i podnacionalne politike i okružja prijetnji traže odgovore prilagođene lokalnim zajednicama. U ovoj studiji o politici nalazi se niz konkretnih političkih inicijativa s posebnom važnošću za zapadni Balkan, od nastojanja da se izgradi otpornost na ekstremizam na internetu koja kreće od građanstva do nastojanja da se reguliraju štetni internetski sadržaji koja kreću od državnog vrha. U ovim se odgovorima naglašavaju potencijalne metode regionalne suradnje i integriranih napora u kojima je prepoznato da je izazov ekstremizma na internetu s kojim je suočen zapadni Balkan suštinski transnacionalan i da se sustavno može riješiti samo kombinacijom odgovora na razini zemalja i koordiniranim regionalnim inicijativama.

27 Louis Reynolds i Ralph Scott, Digital Citizens: Countering Extremism Online (London: Demos, 2016.), https://www.demos. co.uk/wp-content/uploads/2016/12/Digital-Citizenship-web-1.pdf.

28 Ibid.

29 Program Be Internet Citizens pruža primjer međunarodnog kurikula koji je usmjeren na usađivanje navedenih vještina. Pogledajte: https://internetcitizens.withyoutube.com/. 


\section{Predložena daljnja literatura}

\section{O regionalnim izazovima ekstremizma}

Azinović, Vlado. Regional Report: Understanding Violent Extremism in the Western Balkans. British Council Extremism Research Forum, 2018. https://www.britishcouncil.me/sites/default/files/erf report western balkans 2018.pdf

Beslin, Jelena, i Marija Ignjatijevic. Balkan foreign fighters: from Syria to Ukraine. Bruxelles: Institut za sigurnosne studije Europske unije, 2017. https://www.iss.europa.eu/sites/default/files/EUISSFiles/ Brief\%2020\%20Balkan\%20foreign\%20fighters.pdf.

Morina, Engjellushe, Beatrix Austin, Tim Jan Roetman, i Véronique Dudouet. Community Perspectives on Preventing Violent Extremism: Lessons learned from the Western Balkans. Berlin: Berghof Foundation, 2019. https://www.berghof-foundation.org/fileadmin/redaktion/Publications/Other Resources/ WB PVE/CTR PVE WesternBalkans Research Report.pdf

Stronski, Paul, i Annie Himes. Russia's Game in the Balkans. New York: Carnegie Endowment for International Peace, 2019. https://carnegieendowment.org/files/Stronski Himes Balkans formatted.pdf

\section{Profili na razini zemalja}

Bosna i Hercegovina: Understanding Perceptions of Violent Extremism and Foreign Influence. Washington, DC: Međunarodni republički institut, 2018. https://www.iri.org/resource/new-bosnia-andherzegovina-poll-citizens-pessimistic-about-future-vulnerable-outside

Bosnia's Dangerous Tango: Islam and Nationalism. Sarajevo/Bruxelles: Međunarodna krizna skupina, 2013. https://www.crisisgroup.org/europe-central-asia/balkans/bosnia-and-herzegovina/bosnia-sdangerous-tango-islam-and-nationalism

Kosovo Wide Assessment of Perceptions of Radicalisation at the Community Level. Priština: Republika Kosovo, 2017. http://www.ks.undp.org/content/dam/Kosovo/docs/PVE/UNDP KS-Wide\%20Assessment eng web.pdf.

Milanović, Boris. „Mapping Extremist Discourse among Serbian 4Chan /pol/ Users." In Extremism and Violent Extremism in Serbia, 21st Century Manifestations of an Historical Challenge urednik Valery Perry, travanj 2019.

Qehaja, Florian, i Skender Perteshi. The Unexplored Nexus: Issues of Radicalisation and Violent Extremism in Macedonia, Priština: Kosovski centar za sigurnosne studije, 2018. http://www.qkss.org/repository/ docs/Extremism in macedonia 402663.pdf.

Shtuni, Adrian. Dynamics of Radicalization and Violent Extremism in Kosovo. Washington D.C.: Američki institut za mir, Special Report 397, 2016. https://www.usip.org/sites/default/files/SR397-Dynamics-of-Radicalization-and-Violent-Extremism-in-Kosovo.pdf

\section{O postojećim inicijativama regionalne politike}

Europska komisija. „European Commission launches Digital Agenda for the Western Balkans.” Priopćenje za tisak, 25. lipnja 2018. http://europa.eu/rapid/press-release IP-18-4242 en.htm. 
OESS. The Role of Civil Society in Preventing and Countering Violent Extremism and Radicalization that Lead to Terrorism: A Guidebook for South-Eastern Europe. Beč: Organizacija za europsku sigurnost i suradnju (OESS), 2018. https://www.osce.org/files/f/documents/2/2/400241 1.pdf.

Vijeće za regionalnu suradnju. „Initiatives to Prevent/Counter Violent Extremism in South East Europe.” 9. kolovoza 2016. https://www.rcc.int/pubs/38/annual-report-of-the-secretary-general-of-theregional-cooperation-council-2017-2018.

\section{Izvori}

Azinović, Vlado. Regional Report: Understanding Violent Extremism in the Western Balkans. British Council, 2018. https://www. britishcouncil.me/sites/default/files/erf report western balkans 2018.pdf.

„Balkan Terror Trials Reveal Links to Western Europe.” Balkanska istraživačka mreža, 9. siječnja 2018., https://balkaninsight. com/2018/01/09/balkan-terror-trials-reveal-links-to-western-europe-01-08-2018/.

Be Internet Citizens. https://internetcitizens.withyoutube.com/.

Bernstein, Joseph. „The Internet's United Nations Of White Nationalists.” Buzzfeed News, 24. lipnja 2015., https://www.buzzfeednews.com/article/josephbernstein/the-internets-united-nations-of-white-nationalists.

Bosna i Hercegovina, Vijeće ministara. Strategy of Bosnia and Herzegovina for Preventing and Combating Terrorism 2015-2020. Sarajevo: 2015. https://wb-iisg.com/wp-content/uploads/bp-attachments/6102/STRATEGIJA ZA BORBU PROTIV TERORIZMA ENG.pdf.

Centre for Common Ground. https://ccg.org.mk/.

Cosic, Jelena, Lawrence Marzouk, i Ivan Angelovski. „,British Nationalist Trains Serb Far-Right for 'Online War,'” Balkan Insight, 1. svibnja 2018. http://www.balkaninsight.com/en/article/british-nationalist-trains-serb-far-right-for-online-war--04-30-2018.

Vijeće ministara Republike Albanije (Odluka br. 930). Albanian National Strategy: Countering Violent Extremism. Narodne novine Republike Albanije (203/2015), 18. studenog 2015., neslužbeni prijevod. https://cve.gov.al/wp-content/uploads/2018/11/ strategjia-2018-me-ndryshime.pdf.

Davey, Jacob, Henry Tuck, i Amarnath Amarasingam. „An imprecise science: Assessing interventions for the prevention, disengagement and de-radicalisation of left and right-wing extremists." ISD Global, studeni 2019. https://www.isdglobal.org/wp-content/uploads/2019/11/An-imprecise-science.pdf.

Dogani, Besim, i Nayla Joy-Zein. „SCN's Local Prevention Network Model Expands to the Western Balkans.” Strong Cities Network, 9. listopada 2019. https://strongcitiesnetwork.org/en/lpn-model-expands-to-the-western-balkans/.

Eisentraut, Sophie, i Stephanie de Leon. Propaganda and Disinformation in the Western Balkans: How the EU Can Counter Russia's Information War. Berlin: Konrad Adenauer Stiftung, 2018. http://www.kas.de/wf/doc/kas 51729-544-2-30. pdf?180306092933.

Vlada Crne Gore, Ministarstvo pravosuđa. Countering Violent Extremism Strategy 2016-2018. Podgorica: prosinac 2015. https:// wb-iisg.com/wp-content/uploads/bp-attachments/6160/Countering-violent-extremism-strategy-2016-2018.pdf.

Vlada Republike Makedonije, Nacionalni odbor za suzbijanje nasilnog ekstremizma i suzbijanje terorizma. National Counterterrorism Strategy of the Republic of Macedonia (2018-2022). Skopje: veljača 2018. https://wb-iisg.com/wp-content/uploads/ bp-attachments/6135/ct national strategy eng translation sbu.pdf. 
Vlada Republike Srbije. National Strategy for the Prevention and Countering of Terrorism for 2017-2021. https://wb-iisg.com/ wp-content/uploads/bp-attachments/6200/Serbian-National-Strategy-for-the-prevention-and-countering-of-terrorism-for-2017-2021.docx.pdf.

Horwitz, Jeff, i Deepa Seetharaman. „Facebook Executives Shut Down Efforts to Make the Site Less Divisive.” Wall Street Journal, 26. svibnja 2020. https://www.wsj.com/articles/facebook-knows-it-encourages-division-top-executives-nixed-solutions-11590507499.

Hussain, Murtaza. „From El Paso to Sarajevo: How White Nationalists have been Inspired by the Genocide of Muslims in Bosnia.” The Intercept, 1. rujna 2019. https://theintercept.com/2019/09/01/bosnian-genocide-mass-shootings/.

Institute for Strategic Dialogue (ISD). Mreža digitalnog laboratorija politika i tvoraca politika. https://www.isdglobal.org/ programmes/policy-government-advisory/policy-planners-network/.

- - - Inicijativa za građansku hrabrost na internetu. https://www.isdglobal.org/programmes/communications-technology/ online-civil-courage-initiative-2-2/.

„Joint Action Plan on Counter-Terrorism for the Western Balkans.” Europska komisija, 5. listopada 2018. https://ec.europa.eu/ home-affairs/sites/homeaffairs/files/news/docs/20181005 joint-action-plan-counter-terrorism-western-balkans.pdf.

Kelmendi, Vesë, i Rudinë Jakupi. Countering the Myths of IS: How to Counter the IS Narrative Online? The Case of Albanian-Speaking Countries. Priština: Kosovski centar za sigurnosne studije, 2019. http://www.qkss.org/repository/docs/Countering-ISIS-myths-eng 724280.pdf.

Marin Lessenski, „Just think about it: Findings of the Media Literacy Index 2019,” Open Society Institute, Policy Brief 55, 2019. https://osis.bg/wp-content/uploads/2019/11/MediaLiteracylndex2019 -ENG.pdf.

Milekic, Sven. „Croatia's Far Right Draws Strength from Diaspora.” Balkan Insight, 5. siječnja 2018. https://balkaninsight. com/2018/01/05/croatian-far-right-draws-strength-from-diaspora-01-04-2018/.

Vijeće za regionalnu suradnju. „Balkan 'Social Media Jihadis' More Dangerous than Ex-Fighters.” 20. prosinca 2019. https://www. rcc.int/p-cve/news/259/balkan-social-media-jihadis-more-dangerous-than-ex-fighters.

Republika Kosovo, Ured premijera. Strategy on Prevention of Violent Extremism and Radicalisation Leading to Terrorism 20152020. Priština: rujan 2015. https://wb-iisg.com/wp-content/uploads/bp-attachments/6122/STRATEGY-on-PVERLT parandalim - ENG.pdf.

Reynolds, Louis, i Ralph Scott. Digital Citizens: Countering Extremism Online. London: Demos, 2016. https://www.demos.co.uk/ wp-content/uploads/2016/12/Digital-Citizenship-web-1.pdf.

„Serbia the only WB country with more trust in the government than in the EU." European Western Balkans, 6. kolovoza 2019. https://europeanwesternbalkans.com/2019/08/06/serbia-the-only-wb-country-with-more-trust-in-the-government-thanin-the-eu/.

Shehaj, Albana. „After the Pandemic: Perils and Promise for Western Balkans.” Balkan Insight, 20. travnja 2020. https://balkaninsight.com/2020/04/20/after-the-pandemic-perils-and-promise-for-western-balkans/. 


\section{O studiji}

Autori: Milo Comerford i Simeon Dukic

Milo Comerford viši je voditelj za politiku i istraživanje koji upravlja radom instituta Institute for Strategic Dialogue (ISD) u razvoju inovativnih istraživačkih pristupa i političkih odgovora na islamistički ekstremizam. Milo redovito iscrpno informira više donositelje odluka diljem svijeta o izazovu koju sa sobom nose ekstremističke ideologije i savjetuje vlade i međunarodne agencije o izradi učinkovitih strategija za suzbijanje ekstremizma. Njegovi radovi i istraživanja često se pojavljuju u međunarodnim medijima, uključujući Guardian, CNN, Wall Street Journal, Sunday Times, Spectator i New Statesman, a nedavno je nastupao na televizijskim programima BBC News, Sky News i Al Jazeera.

Simeon Dukić voditelj je za Balkan i srednju Aziju na ISD-jevoj mreži Strong Cities Network (SCN). Njegov je rad usredotočen na pružanje podrške zainteresiranim dionicima nacionalne i lokalne vlade u jačanju nacionalno-lokalne koordinacije i suradnje na sprječavanju i suzbijanju nasilnog ekstremizma. Simeon je surađivao s brojnim članovima SCN-a diljem regija kako bi uspostavio višedisciplinarne mreže s više dionika za lokalnu prevenciju te podržao izradu i provedbu prilagođenih lokalnih akcijskih planova sprečavanja / borbe protiv nasilnog ekstremizma.

Autori izražavaju zahvalnost Mubarazu Ahmedu i Garentini Kraja zbog njihovih istraživačkih i političkih uvida koji su pomogli oblikovati ovu studiju o politici.

Stajališta navedena u ovoj publikaciji stajališta su autorā. Ona nužno ne odražavaju stajališta mreže RESOLVE, Američkog instituta za mir ili bilo kojeg tijela Vlade Sjedinjenih Država.

MREŽA RESOLVE bolje istraživanje.informirana praksa•poboljšana politika o nasilnom ekstremizmu.

www.resolvenet.org

Y $f$ in

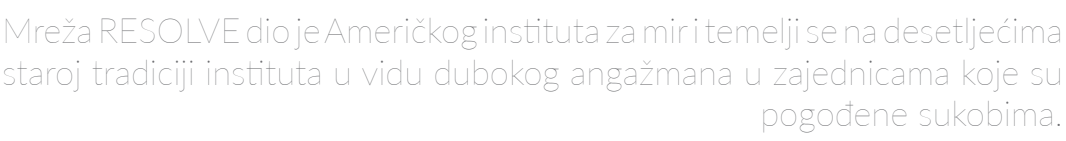

United STATES

Institute of Peace Making Peace Possible 